Global Conferences Series:

Sciences and Technology (GCSST), Volume 3, 2020

The $1^{\text {st }}$ International Conference on Education, Sciences and Technology

DOI: https://doi.org/10.32698/tech3237

\title{
Student Psychological Responses to English For Biology Course in Biology Department of Universitas Negeri Padang
}

\author{
Lufri, Relsas Yogica \\ Biology Department, Mathematic and Natural Science Faculty \\ Universitas Negeri Padang
}

relsasyo@fmipa.unp.ac.id

\begin{abstract}
Education at the university expects graduates who are able to integrate with social life, including with international life. Students who graduate become a benchmark for the quality of the place they study. So, the quality of a university depends on the quality of the individual graduates. The quality of graduates is marked by their achievement index at the end of each semester. Students who have high intelligence have the possibility of getting high scores, and vice versa. The "English for Biology" course is an effort to harmonize the world's needs of qualified graduates with the role of the university's function as a place to prepare it. In each lecture will appear a variety of student responses psychologically to the lectures that are happening. These responses include perceptions, interests and attitudes. The response has an effect on student competence after lecturing. We have observed these psychological responses using questionnaire, and we had analyze them on Biology Department students at Universitas Negeri Padang. The result shown about student's perception, interest and attitude.
\end{abstract}

\section{Introduction}

Education is a continuous process to improve human quality through academic activities. The activity is carried out by teachers, students, and education staff together. These components do not play their respective roles separately. The success of the educational process that occurs in the classroom is determined by several factors.

The determinants of educational success come from within the learner and from the environment. Both of these factors play an important role as a reference for success. Environmental factors include the strategies and methods used by teachers in learning, learning tools and social conditions of the community. While internal factors include learning styles ${ }^{[1]}$, psychological responses, motivation and metacognition.

In some cases, internal factors can be directly influenced by environmental factors. Then the affected internal factors can also be the foundation of successful learning. These internal factors are psychological responses, which include perceptions, interests and learners' attitudes towards learning methods and teaching materials delivered during learning.

Psychological responses can affect learning outcomes, because psychological response is an unconscious state that cannot be controlled by each individual. This response arises from outside treatment. A good response to learning will lead to good learning outcomes. So, we deserve to 
conclude that learning methods and learning materials can influence one's learning outcomes, through the integration of these factors with psychological responses.

We have observed the psychological response of Biology Department students at the Faculty of Mathematics and Natural Sciences, Universitas Negeri Padang in the "English for Biology" course. This course is an effort so that students have the ability to interact in an international scope. English as an international language is very important for students to understand, at least to interpret existing scientific writings.

\section{Literation}

\subsection{Student's perception}

Perception is an assumption that exists in a person towards something, which is one component of cognitive ability ${ }^{[2]}$. Perception can be the basis of thinking for that person ${ }^{[3]}$. Student perception is one form of students' psychological response to things that have a learning process. Student perceptions can be formed by the methods used by teachers in the classroom to carry out learning. Quality teachers are teachers who can create good perceptions for students ${ }^{[4]}$. Perception formed will influence student interest in learning ${ }^{[4]}$, also affect learning motivation ${ }^{[5]}$ and confidence in self ${ }^{[6]}$. A student's perception is also influenced by age $\mathrm{and}^{[7]}$ and gender ${ }^{[8]}$.

Students' perceptions of learning, whether learning methods ${ }^{[9]}$, learning models ${ }^{[10]}$, and teaching materials, are very important to know by the teacher. Perception should be measured in order to change the perception of the bad to be better, so that students can improve their learning abilities ${ }^{[10]}$. Although some studies show a weak relationship between perceptions of learning on affective and psychomotor competencies ${ }^{[10]}$. Students' perceptions of things are very important to know, especially in the introduction and use of technology ${ }^{[11]}$. Another advantage that can be felt by identifying student perceptions is that the teacher can group students in certain classes/ groups according to their perceptions ${ }^{[12]}$. Teachers' perceptions in learning can also be an important study material which is no less important ${ }^{[13]}$.

\subsection{Student's interest}

Students who have an interest in learning have the opportunity to get a meaningful, long-term, and good job learning process ${ }^{[14]}$. Optimal learning outcomes can be achieved because there is interest in students to learn ${ }^{[15][16][17]}$. Interest in learning is influenced by learning media used ${ }^{[18]}$, for example online media - Pinterest ${ }^{[19]}$ and television ${ }^{[20]}$. In addition, interest in learning can also be influenced by the learning methods used by the teacher, the type of teaching material ${ }^{[21]}$, and the learning $\operatorname{approach}^{[22]}$.

\subsection{Student's attitude}

Attitude is a result of one's judgment of an event, as well as someone else ${ }^{[23][24]}$. The results of the assessment make students show a response to the learning process. For example, the attitude of willingness to learn, arises from the assessment that learning requires initiative, responsibility, discipline and confidence ${ }^{[25]}$. A good attitude can bring good learning outcomes ${ }^{[26]}$. Teachers are asked to design learning so that they can make a positive attitude for students, such as video games based learning ${ }^{[27][28]}$. Learning attitudes can also be influenced by non-academic factors, namely residence and age ${ }^{[29]}$. Analysis of learning attitudes can be an ingredient for choosing and using effective and innovative learning models ${ }^{[30]}$. 


\section{Method}

\subsection{Research initiation}

We have introduced students to the integrated learning method that will be used during lectures. Then we explained that at the end of the lesson, students would be given a questionnaire that had to be answered. Before giving it to respondents, the questionnaire We tested its validity ${ }^{[31]}$.

\subsection{Data collection}

We have collected data using a questionnaire. Although some researchers have used online questionnaires $^{[32]}$, we only use print questionnaires. The reason is that there are not too many respondents.

\subsection{Data tabulation}

\subsection{Data analysis}

\subsection{Conclusion}

\section{Result and discussion}

4.1. Student's perception to the material course (A1) and on learning method (A2)

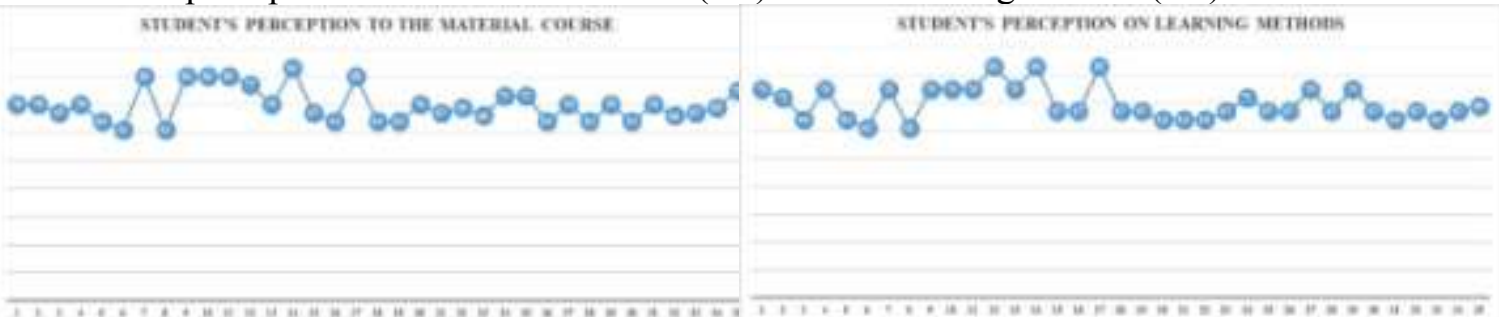

Figure 1. Data of student's perception to the material course and on learning method

We have assessed students' psychological responses to aspects of their perceptions of the learning material they have learned. The highest value in this aspect is 83 and the lowest value is 61 . Only one person has a very good perception value. While others have good perceptions. Very good perception of the material raises a variety of circumstances that allow students to study very diligently. Students' perceptions are directly proportional to the learning outcomes they will achieve $\mathrm{e}^{[4]}$, including those on sociology subjects ${ }^{[10]}$.

Students' perceptions of the learning methods used in lectures also give rise to variations. Most students have good perceptions, in the range 61-75. Three students had very good perceptions, 83 points. This situation can be interpreted that there is an attraction of learning methods for students, this could be because of the element of innovation in it. Not all learning methods can give rise to perceptions that are good or very good for students, depending on the situation ${ }^{[9]}$, one of which is the factor of parents' perceptions of the child's condition ${ }^{[13]}$. We did not calculate the significance value of perceptions of the learning method, but previous research found that there was no significant relationship between perception and the method used by the teacher ${ }^{[12][33]}$. 
4.2. Student's interest to the material course (B1) and on learning method (B2)

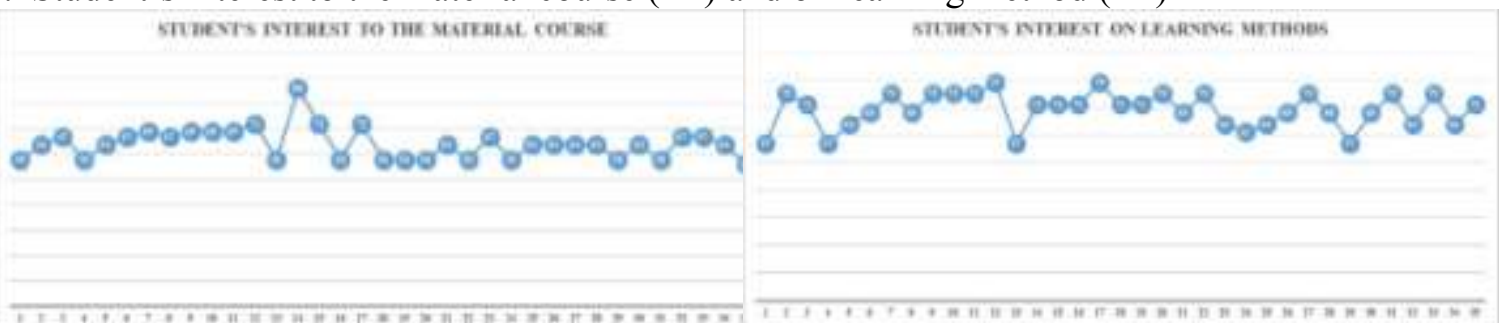

Figure 2. Data of student's interest to the material course and on learning method

Students' interest in learning material for English for Biology shows more diversity compared to A1and A2. There are 12 students who have an interest value at a fairly good level (58 points), one student is interested in a very good level (86 points), and the other is at a good level. Usually, students who are interested in learning in English are those who are accustomed to and have the spirit to understand it. Students who have an interest in learning will focus their attention on this learning ${ }^{[18]}$ so that they can produce good learning achievement ${ }^{[34]}$.

Student interest in the method used also showed unsatisfactory symptoms, even though they were at a good level and quite good. This is because learning with less desirable material can weaken the learning method used. This research proves that the method we use cannot make students interested in learning to a very good level. The right learning method can stimulate the emergence of student learning interest ${ }^{[35][36]}$. The use of learning media, internet and music ${ }^{[37]}$ can be another option for attracting students, as in the subject that is indeed not part of student $l i f \mathrm{e}^{[38]}$, and something that is pleasing to them, such as video games ${ }^{[39]}$.

\subsection{Student's attitude to the material course $(\mathrm{C} 1)$ and on learning method $(\mathrm{C} 2)$}

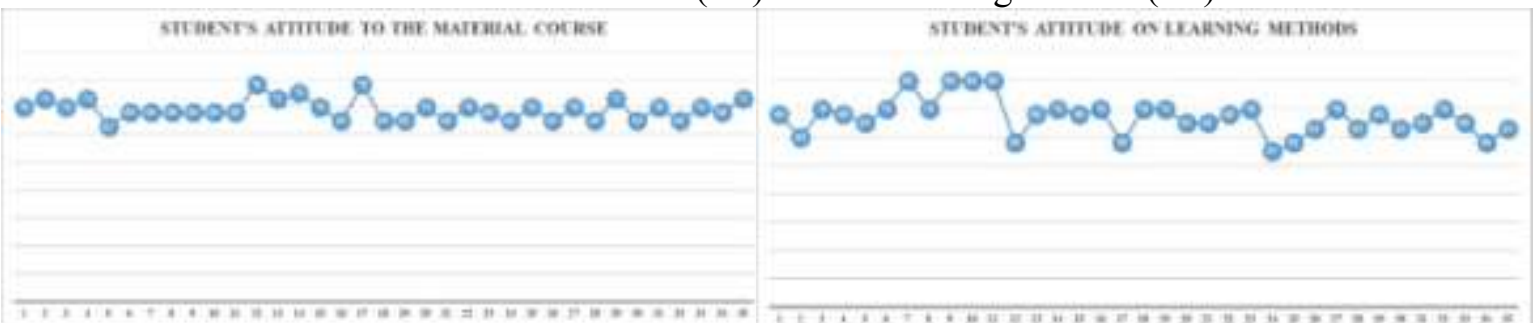

Figure 3. Data of student's attitude to the material course and on learning method

The attitude shown by students during learning, and attitudes that arise after learning are over all are at a good level, namely the range of $65-78$ points. Based on these results, we get information that the English material that has been studied by students is delivered in a method that is not optimal. The right method is very influential on the formation of good attitudes ${ }^{[40]}$.

The attitude of students towards the learning method is at a fairly good and good level (mostly). This attitude can be seen directly by the lecturer who teaches in the class, but we only display quantitative data in this article. The attitude intended in this article is an attitude that can support the learning process, such as seriousness, perseverance and active learning.

\section{Conclusion}

We conclude this study with the statement that the integrated learning method that we use raises different psychological responses from students. These results illustrate that the lecture methods and materials are well received by students. However, the limitations of this study are that there is no further information about any other responses that have arisen and there is no information about how each of these responses appears in the student unit. Further research is needed to find out. 


\section{References}

[1] F. R. Relsas Yogica, "Gaya Belajar Mahasiswa Pendidikan Biologi Tahun Pertama di Jurusan Biologi FMIPA UNP," Pancar. Pendidik., vol. 1, no. 5, pp. 95-104, 2016.

[2] P. Arumingtyas, "STUDI TENTANG CARA BELAJAR SISWA DALAM UPAYA MENINGKATKAN PRESTASI BELAJAR PADA SISWA KELAS II DI SMK BATIK 2 SURAKARTA TAHUN DIKLAT 2005/2006," Skripsi tidak diterbitkan, 2007.

[3] S. W. M. Sari, "Hubungan persepsi belajar dan keaktifan siswa dalam proses pembelajaran dengan prestasi belajar mata pelajaran sosiologi siswa kelas xi ips sma negeri 2 surakarta tahun ajaran 2013/2014.," pp. 1-13, 2014.

[4] R. Muti, "GURU DAN MINAT BELAJAR TERHADAP PRESTASI BELAJAR SISWA DI KELAS X MA SWASTA NUR IBRAHIMY RANTAUPRAPAT TAHUN AJARAN 2015 / 2016," vol. 5, no. 2, 2016.

[5] Idayanti, "Pengaruh Persepsi Siswa Tentang Lingkungan Sekolah Terhadap Motivasi Belajar pada Mata Pelajaran IPS Kelas VIII SMP Negeri 40 Semarang," 2015.

[6] W. H. Chong, G. A. D. Liem, V. S. Huan, P. L. Kit, and R. P. Ang, "Student perceptions of self-efficacy and teacher support for learning in fostering youth competencies: Roles of affective and cognitive engagement," J. Adolesc., vol. 68, no. April 2017, pp. 1-11, 2018.

[7] F. Martin, C. Wang, and A. Sadaf, "Student perception of helpfulness of facilitation strategies that enhance instructor presence, connectedness, engagement and learning in online courses," Internet High. Educ., vol. 37, no. January, pp. 52-65, 2018.

[8] J. A. Schmidt, S. S. Kafkas, K. S. Maier, L. Shumow, and H. Z. Kackar-Cam, "Why are we learning this? Using mixed methods to understand teachers' relevance statements and how they shape middle school students' perceptions of science utility," Contemp. Educ. Psychol., no. xxxx, pp. 1-23, 2018.

[9] T. Okuda, "Student perceptions of non-native English speaking tutors at a writing center in Japan," J. Second Lang. Writ., vol. 44, no. January, pp. 13-22, 2019.

[10] H. Dwi, U. Putri, Y. Fauziah, and E. Febrita, "Hubungan Persepsi dengan Hasil Belajar Siswa pada Pembelajaran Biologi Menggunakan Model Kooperatif Tipe Numbered Heads Together (NHT) Kelas XI IPA Di SMA N 2 Tambang," pp. 1-13.

[11] K. J. Cunningham, "Student Perceptions and Use of Technology-Mediated Text and Screencast Feedback in ESL Writing," Comput. Compos., vol. 52, pp. 222-241, 2019.

[12] Chairunnisa, "PERSEPSI SISWA TERHADAP METODE PEMBELAJARAN GURU DAN HASIL BELAJAR BAHASA INDONESIA DI SMK AL-HIDAYAH CIPUTAT," Skripsi tidak diterbitkan, 2011.

[13] I. Srba, M. Savic, M. Bielikova, M. Ivanovic, and C. Pautasso, "Employing community question answering for online discussions in university courses: Students' perspective," Comput. Educ., 2019.

[14] W. Graber, "German high school students' interest in chemistry - A comparison between1990 and 2008," Educ. Quim., vol. 22, no. 2, pp. 134-140, 2011.

[15] D. Ti. N. Putri, "Pengaruh Minat Dan Motivasi Terhadap Hasil Belajar Pada Mata Pelajaran Pengantar Administrasi Perkantoran," Pendidik. Bisnis dan Manajemen, Univ. Negeri Malang, vol. 1, no. 2, pp. 118-124, 2013.

[16] S. Nurhasanah and A. Sobandi, "Learning Interest as Determinant Student Learning Outcomes," J. Pendidik. Manaj. Perkantoran, vol. 1, no. 1, pp. 135-142, 2016.

[17] Rusmiati, "Pengaruh Minat Belajar Terhadap Prestasi Belajar Bidang Studi Ekonomi Siswa Ma Al Fattah Sumbermulyo," J. Ilm. Pendidik. dan Ekon., vol. 1, no. 1, pp. 21-36, 2017.

[18] K. Anam, "Pengaruh Media Pembelajaran Terhadap Minar Belajar Siswa Pada Mata Pelajaran PAI di SMP Bani Muqiman Bangkalan," Pendidik. Islam, vol. 2, no. 4, p. , 2015.

[19] A. F. Holmes and S. J. Rasmussen, "Using Pinterest to stimulate student engagement, interest, and learning in managerial accounting courses," J. Account. Educ., vol. 43, no. March, pp. 43$56,2018$. 
[20] K. Sriklaub and S. Wongwanich, "Learning Activities Aimed at Promoting Students' Interest: Synthesis of Master Teachers' Activity Organizing Methods via TV Media," Procedia - Soc. Behav. Sci., vol. 116, pp. 3375-3380, 2014.

[21] R. S. Relsas Yogica, Lufri Lufri, "Efektifitas Modul Bergambar Disertai LKS Berorientasi Konstruktivistik Terhadap Proses dan Aktivitas Belajar Siswa dalam Pembelajaran Biologi SMA," Penelit. Pendidik., vol. 5, no. 1, p. , 2014.

[22] M. Voinea and M. Purcaru, "Boosting Romanian Students' Interest in Learning Mathematics through the Constructivist Approach," Procedia - Soc. Behav. Sci., vol. 127, pp. 108-113, 2014.

[23] B. Happell et al., "Nursing student attitudes to people labelled with 'mental illness' and consumer participation: A survey-based analysis of findings and psychometric properties," Nurse Educ. Today, vol. 76, no. January, pp. 89-95, 2019.

[24] M. E. Aleshire, A. Dampier, and L. Woltenberg, "Evaluating Undergraduate Nursing Students' Attitudes Toward Health Care Teams in the Context of an Interprofessionally-Focused Nursing Course," J. Prof. Nurs., vol. 35, no. 1, pp. 37-43, 2019.

[25] A. Saefullah, P. Siahaan, and I. M. Sari, "Hubungan Antara Sikap Kemandirian Belajar Dan Prestasi Belajar Siswa Kelas X Pada Pembelajaran Fisika Berbasis Portofolio,” J. Wahana Pendidik. Fis., vol. 1, no. 1, pp. 26-36, 2013.

[26] Zulhafizh, Atmazaki, and S. R, "KONTRIBUSI SIKAP DAN MOTIVASI BELAJAR SISWA TERHADAP HASIL BELAJAR BAHASA INDONESIA," J. Bhs. Sastra dan Pembelajaran, vol. 1, no. 2, p., 2013.

[27] J. Martí-Parreño, A. Galbis-Córdova, and M. J. Miquel-Romero, "Students' attitude towards the use of educational video games to develop competencies," Comput. Human Behav., vol. 81, no., pp. 366-377, 2018.

[28] M. Barr, "Student attitudes to games-based skills development: Learning from video games in higher education," Comput. Human Behav., vol. 80, pp. 283-294, 2018.

[29] V. Anghelache, "The Non-cognitive Variables of the Students' Attitude towards Learning," Procedia - Soc. Behav. Sci., vol. 128, pp. 44-48, 2014.

[30] N. S. Ashaari, H. M. Judi, H. Mohamed, and T. M. Tengku Wook, "Student's Attitude Towards Statistics course," Procedia - Soc. Behav. Sci., vol. 18, pp. 287-294, 2011.

[31] M. Lucas da Rocha Cunha, F. Amendola, M. M. Fernandez Samperiz, and A. Gomes da Costa Mohallem, "Evaluation of student perception of the Team-based Learning method (APA-TBL): Instrument construction and validation," Nurse Educ. Pract., vol. 33, pp. 141-147, 2018.

[32] R. M. Extavour and G. L. Allison, "Students' perceptions of a blended learning pharmacy seminar course in a Caribbean school of pharmacy," Curr. Pharm. Teach. Learn., vol. 10, no. 4, pp. 517-522, 2018.

[33] Lufri, R. Fitri, and R. Yogica, "Effectiveness of concept-based learning model, drawing and drill methods to improve student's ability to understand concepts and high-level thinking in animal development course," in Journal of Physics: Conference Series, 2018.

[34] N. K. Pratiwi, "Pengaruh Tingkat Pendidikan, Perhatian Orang Tua, Dan Minat Belajar Siswa Terhadap Prestasi Belajar Bahasa Indonesia Siswa Smk Kesehatan Di Kota Tangerang," J. Pujangga, vol. 1, no. 2, pp. 75-105, 2015.

[35] M. Ogbari et al., "The effect of non traditional teaching methods in entrepreneurship education on students entrepreneurial interest and business startups: A data article," Data Br., vol. 19, pp. 16-20, 2018.

[36] R. Yogica and H. Helendra, "They do, They Get and They Know; How to Motivate Learner to Upgrade Their Learning Quality," in IOP Conference Series: Materials Science and Engineering, 2018.

[37] P. R. Brandon and B. E. Lawton, "The development, validation, and potential uses of the student interest-in-the-arts questionnaire," Stud. Educ. Eval., vol. 39, no. 2, pp. 90-96, 2013.

[38] D. Y. P. H. Amjah, "A Study of Teachers' Strategies so Develop Students' Interest towards 
Learning English as a Second Language," Procedia - Soc. Behav. Sci., vol. 134, pp. 188-192, 2014.

[39] B. Manero, J. Torrente, Á. Serrano, I. Martínez-Ortiz, and B. Fernández-Manjón, "Can educational video games increase high school students' interest in theatre?, Comput. Educ., vol. 87, pp. 182-191, 2015.

[40] S. Ciftci, "The Effects of Using Project-Based Learning in Social Studies Education to Students' Attitudes towards Social Studies Courses," Procedia - Soc. Behav. Sci., vol. 186, pp. 1019-1024, 2015. 